\title{
Theoanthropocentric: Learning Strategies for Improving Students' Conceptual Understanding
}

\author{
Muhammad Darwis Dasopang \\ Institut Agama Islam Negeri Padangsidimpuan \\ Email: mhddasopang@iain-padangsidimpuan.ac.id
}

\begin{abstract}
Learning objectives can be achieved in various ways, one of which is by implementing learning strategies. This study aims to explore the effectiveness of Theoanthropocentric learning strategies for improving students' conceptual understanding skills. The research population is all junior high school students (SMP), and the sample comprises students from class VIII. The random cluster sampling technique was used to choose the study's sample. The data collection method used in this research is the conceptual understanding test. Descriptive and inferential statistics serve for data analysis, including the independent t-test. The results show a significant difference between the conceptual understanding of students who used Theoanthropocentric learning strategies and those who did not use Theoanthropocentric learning strategies. The descriptive statistical test results show that the students in the experimental group have a higher mean score than students in the control group. The independent $\mathrm{t}$-test result has strengthened the statistical test results, namely, 0.00 ( $\mathrm{p}<0.05)$, from the finding, it follows that the application of theoanthropocentric learning strategies has an enormous impact on improving students' conceptual understanding skills. Therefore, the Theoanthropocentric approach could be used as a solution to improve students' conceptual understanding skills.
\end{abstract}

Keywords: Effectiveness; Learning strategies; Theoanthropocentric; Conceptual understanding; Knowledge

\footnotetext{
Abstrak

Tujuan pembelajaran dapat dicapai dengan berbagai cara, salah satunya dengan menerapkan strategi pembelajaran. Penelitian ini bertujuan untuk mengeksplorasi keefektifan strategi pembelajaran Theoanthropocentric untuk meningkatkan keterampilan pemahaman konseptual siswa. Populasi penelitian adalah seluruh siswa Sekolah Menengah Pertama (SMP), dan sampelnya adalah siswa kelas VIII. Teknik pengambilan sampel cluster acak digunakan untuk memilih
} 


\section{Fitrah \\ $\triangle$ Jurnal Kajian Ilmu-ilmu Keislaman}

Vol. 6 No. 2 December 2020

sampel penelitian. Metode pengumpulan data yang digunakan dalam penelitian ini adalah tes pemahaman konseptual. Statistik deskriptif dan inferensial berfungsi untuk analisis data, termasuk uji$\mathrm{t}$ independen. Hasil penelitian menunjukkan adanya perbedaan yang signifikan antara pemahaman konseptual siswa yang menggunakan strategi pembelajaran Theoanthropocentric dan yang tidak menggunakan strategi pembelajaran Theoanthropocentric. Hasil uji statistik deskriptif menunjukkan bahwa siswa pada kelompok eksperimen memiliki nilai rata-rata yang lebih tinggi daripada siswa pada kelompok kontrol. Hasil uji $t$ independent memperkuat hasil uji statistik yaitu $0,00(\mathrm{p}<0,05)$, dari temuan tersebut dapat disimpulkan bahwa penerapan strategi pembelajaran teoantroposentris memiliki pengaruh yang sangat besar terhadap peningkatan keterampilan pemahaman konseptual siswa. Oleh karena itu, pendekatan Theoanthropocentric dapat digunakan sebagai solusi untuk meningkatkan kemampuan pemahaman konseptual siswa.

Kata Kunci: Efektivitas; Belajar strategi; Teoantroposentris; Pemahaman konseptual; Pengetahuan

\section{INTRODUCTION}

The achievement of learning objectives is the main goal of educational programs. Meanwhile, education encompasses the interaction between individuals and their environment to increase knowledge, instill the right attitude, and improve their skills (Schunk, 2012). There are many challenges in the learning process, including the lack of student motivation (Wardani et al., 2020), difficulties in designing learning media (Palobo et al., 2018), the lack of teachers (Diem \& Thathong, 2019), and students' difficulty in understanding the concept of learning. In this light, the lack of students' understanding makes it difficult for them to optimize their critical thinking skills in solving problems inside and outside the classroom (Al-Shehri, 2020). All of these problems have an impact on poor student learning outcomes. There are various ways to help students achieve learning goals. These include using technology-based learning media (Lubis \& Wangid, 2019), using games to increase student motivation (Ding, Guan \& Yu, 2017), and adopting learning strategies (Schoenfeld, 2016). These efforts help facilitate learning objectives to ensure the targeted learning objectives could be achieved and the success of the learning process (Wolfolk, 2016). One essential aspect that should be considered when setting learning 
objectives is the realm of student knowledge. This is because it reflects their ability to understand the new concepts taught (Kalelkar, 2017). Students need to understand the concept as it allows them to follow the learning process and achieve the learning goals (Santrock, 2011).

Understanding new concepts can help students to comprehend the images of the materials presented in the learning process (Asfar \& Asfar, 2020). Furthermore, it can help them think systematically, logically, and hierarchically from the simplest to the most complex (Putra, Nur Kholifah, Subali \& Rusilowati, 2018). Anderson et al. (2001) argued that students' conceptual understanding skills could be reflected by their ability to understand the learning materials provided, apply them in everyday life, and relate them to other contexts. Based on this opinion, teachers must help students understand, apply, and connect the concept they have learned in everyday life.

Several benchmarks could be used to measure students' conceptual understanding. Instruments adopted from Clements, Sarama, and DiBiase (2003); Marsh, Golledge, and Battersby (2007); Osborne and Gilbert (1980) are based on the notion that students with good conceptual understanding skills will be able to repeat the lessons delivered quickly (Donisch, Bray \& Gewirtz, 2016). Understanding a concept is also reflected through one's ability to classify objects and apply them in everyday life (Andayani, Hadisaputra \& Hasnawati, 2018). Another study by Andamon and Tan (2018) stated that students' ability to understand concepts could be measured through their ability to restate information obtained in their language and relate them to other contexts. Kurniasih, Hidayah, and Asikin (2020) stated that solving daily problems is part of students' understanding of the concepts taught in the learning process. Based on the above discussion, the indicators of students' conceptual understanding in this study include their ability to, first, restate the concept learned; second, classify the object introduced; third, apply the concept in other contexts; fourth, present the information received into another perspective, and lastly, link the information received with different contexts.

Teachers could improve students' conceptual understanding skills by applying the suitable learning strategies (Biggerstaff, Mitbander \& Webster, 1994; Edmondson, 2005). One of the learning strategies that can improve students' conceptual understanding skills is the Theoanthropocentric learning strategy. Theoanthropocentric learning strategy, which is a variable in this study, is a 


\section{Fitrah \\ $\rightarrow$ Jurnal Kajian Ilmu-ilmu Keislaman}

Vol. 6 No. 2 December 2020

development of contextual learning strategies, namely learning that connects the concepts received during the learning process with the context of everyday life (Johnson, 2006; Perkinson, 2012). This contextual learning strategy is combined with Theocentric and Anthropocentric elements to form a learning strategy called the Theoanthropocentric approach. Theoanthropocentric learning strategy is a combination of two words: Theocentric, which means centered on God, and Anthropocentric, which means centered on human life. Quay (2003) explained that knowledge in life comes from two sources, God's experience and expertise that comes from humans themselves. In line with the opinion of Gwen (2012) and Quay (2003), religious teachings do not spread on their own; rather, there is an intervention from human reason that helps to spread spiritual knowledge. The spread of earthly knowledge is inseparable from God. This is because God's revelation is the ultimate source of knowledge, while man acts as a source of knowledge through the optimization of his mind. Kim (2018) explained that Theoanthropocentric is a system that integrates transmitted expertise and acquired knowledge integrally through an interdisciplinary scientific approach. Based on the above argument, the Theoanthropocentric learning strategy referred to in this study is a contextual learning strategy applied to the learning process with divine revelation as a guide and optimization of human reason to achieve life's existence.

Theoanthropocentric learning strategy is a form of contextual learning strategy which encompasses several contextual strategy learning steps. According to the Center for Occupational Research and Development (CORD), the contextual learning step consists of five stages: Relating, Experiencing, Applying, Cooperating, and Transferring (Danver, 2016; Mackinnon, 2010). Based on the explanation, Theoanthropocentric learning strategy comprises of several learning steps, which are (1) connecting students' learning experiences with the students' social and spiritual contexts; (2) involve students actively in linking their social and spiritual experiences with learning; (3) students application of the knowledge gained during education to their social and spiritual life; (4) students' involvement or co-operation in learning and (5) enabling the transformation of knowledge as a form of students' social relations.

Based on the preliminary study results, students in the state-owned junior high school in the city of Padangsidimpuan faced several issues in learning 
Islamic Religious Education. One of the major issues is students' low achievement in Islamic Religious Education. In this regard, such low achievement is linked to teachers' use of monotonous learning strategies in the learning process, which has lowered students' interest or motivation in learning (Riswanto \& Aryani, 2017). Jack and Lin (2017) stated that the lack of interest in learning makes it difficult for students to achieve the learning goals. Despite various attempts to improve students' conceptual understanding, the efforts made so far have not shown the expected result. These findings indicate the need for teachers to implement a suitable learning strategy to help improve students' achievement in Islamic Religious Education. Thus, this study focuses on the implementation of the Theoanthropocentric contextual learning strategy. In this regard, embedding the Theoanthropocentric process into the contextual learning strategy is a new step to solve these problems.

The focus of studies to improve students' conceptual understanding so far tends to be divided into two aspects; the use of a learning approach and learning media. Khatimah and Sugiman (2019) revealed that teachers' use of the problemsolving approach during the learning process could improve students' understanding of concepts. Furthermore, Corona, Alaniz, and Akata (2019) stated that learning media could help students make sense of the images. In this light, there is still no study that focused on learning strategies that combine social relationships (relationships with other humans) and spirituality (relationships with God) to improve students' conceptual understanding. To fill this gap, the study tries to use a learning strategy to facilitate the learning of spiritual and academic knowledge. This strategy is called the Theoanthropocentric strategy. In this study, the Theoanthropocentric learning strategy was adopted to increase students' conceptual understanding. This research examines the effect of the Theoanthropocentric learning strategy on students' conceptual understanding ability in learning Islamic Religious Education (PAI).

\section{RESEARCH METHOD}

This study is a quantitative study that the research design used a quasiexperimental. Students from two randomly selected classes, each from a different school, were chosen as samples. They are assumed to have the same characteristics (homogeneous), as evidenced by the homogeneity test results. One class of students group was used as the treatment class and control group for another class (Gall, Borg \& Gall, 1996). The two groups were initially taught 


\section{Fitrah \\ I Jurnal Kajian Ilmu-ilmu Keislaman}

Vol. 6 No. 2 December 2020

using the learning strategies, and a pre-test was conducted to measure their conceptual understanding ability at the beginning. The students for experimental conditions were taught using the Theoantrhopocentric strategy, while the control class used the expository approach. Throughout the treatment, the students were given different tests to measure their conceptual understanding abilities before and after they were taught using the Theoanthropocentric approach. The students were also given a post-test towards the end learning process. The difference between the pre-test and post-test results carried out to assess whether there is a treatment effect. The study was conducted in the city of Padangsidimpuan, North Sumatra, Indonesia. The study's population comprises students in 11 junior high schools (SMP) in Padangsidimpuan. The cluster random sampling technique was used to determine the sample. This study's samples are class VIII students in SMP Negeri 3 Padangsidimpuan and eighthgrade students in SMP Negeri 6 Padangsidimpuan. The students of eighth-grade class from SMP Negeri 3 Padangsidimpuan were put in the experimental group where they were taught using the Theoanthropocentric strategy. Meanwhile, the eighth-grade students from SMP Negeri 6 Padangsidimpuan were put in the control group where they were taught using expository strategy commonly used by teachers.

This study was conducted in several stages, namely (1) conducting a preliminary study; (2) research planning, (3) compiling research instruments; (4) testing the validity of research instruments; (5) determining the research sample; (6) conducting a pre-test for the experimental class and control class; (7) carry out learning; (8) doing post-test after learning; (9) perform data analysis; and (10) concluding the data were collected through a conceptual understanding test instrument that contains multiple-choice questions. The students were given the pre-test and post-test instrument, which adopted the Theoathropocentric learning strategy to measure their conceptual understanding skills in learning Islamic Education. The quantitative data obtained were analyzed using descriptive statistics and inferential statistics. Descriptive statistics were used to determine the students' average pre-test and post-test results. A paired t-test was also performed to find out the differences in the students' conceptual understanding in the experimental group before learning using the Theoanthropocentric learning strategy. The inferential statistical analysis 
(independent t-test) was carried out to test whether any differences existed between the experimental and control groups' post-test results and determine the Theoanthropocentric strategy's effectiveness (Huck, Cormier \& Bounds, 1974).

\section{RESEARCH FINDINGS AND DISCUSSION}

\section{Findings}

A descriptive statistical analysis of the pre-test and post-test scores was conducted to test for differences between the two groups. It became evident that the mean pre-test result for students in the treatment group is 72.34 and the mean increased to 85.78 for the post-test, indicating a mean score increase of 13.44. For students group of control, the average pre-test result is 68.13 , which increased to 73.91 in the post-test. There is an increase of 5.78 in the average post-test score on the students' conceptual understanding ability. The difference between the average pre-test and post-test scores is more significant among the experimental group students than in the control group. Hence, students who learned using the Theoanthropocentric learning strategy show a more significant increase in the average score than students who were not exposed to Theoanthropocentric learning strategy. Figure 1 presents the students' average scores on their conceptual understanding ability.

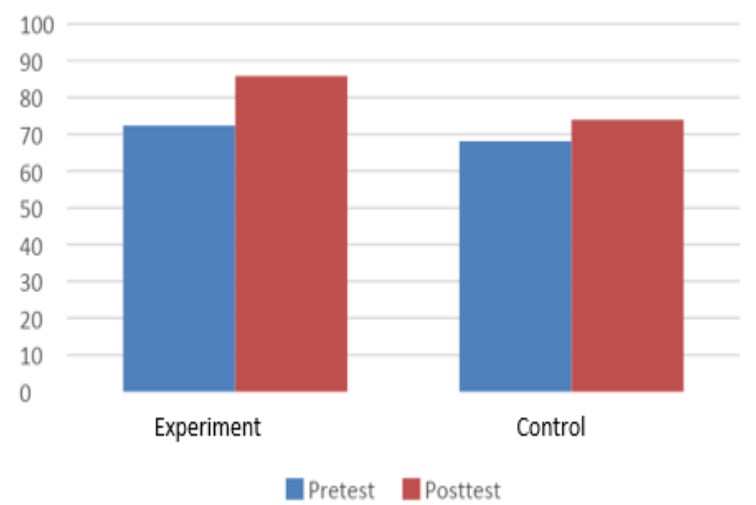

Figure 1: The results of the pre-test and post-test students' conceptual understanding ability

As shown in Figure 1, the students' mean post-test result in the treatment group is on high those in the control group. The higher outcome indicates that the use of Theoanthropocentric learning strategies can positively affect students' conceptual understanding abilities.

An independent $t$-test was performed to measure the students' conceptual understanding ability. Before carrying out the t-test, a prerequisite 


\section{Fitrah \\ $\triangle$ Jurnal Kajian Ilmu-ilmu Keislaman}

Vol. 6 No. 2 December 2020

test for normality and homogeneity was carried out on the data obtained to determine the suitable statistical testing procedure to be used. The normality test results indicate that the data obtained to meet the assumptions of normal distribution. Furthermore, the homogeneity test results show that the data come from a homogeneous population. Thus, the data has fulfilled the normality and homogeneity prerequisite to perform parametric statistical tests, specifically a $\mathrm{t}$ test.

Before conducting the independent $\mathrm{t}$-test, a paired $\mathrm{t}$-test was conducted to assess whether there was a differences existed between the students' conceptual understanding in the experimental group before participating in learning using the Theoanthropocentric learning strategy. The paired t-test results showed that the Sig 2-tailed value is $0.00(p<0.05)$. The conclusion drawn through this paired $\mathrm{t}$-test is that there is a difference in the students' conceptual understanding before and after participating in learning using Theoanthropocentric learning strategies. An independent $\mathrm{t}$-test was carried out to test whether any differences existed between students who learned using the Theoanthropocentric learning strategy (experimental group) and those who did not (control group). Table 1 presents the independent t-test results on the data about students' conceptual understanding ability.

Table 1: Independent t-tes

\begin{tabular}{|l|c|c|c|}
\hline \multirow{2}{*}{ Variabel } & \multicolumn{2}{|c|}{ Equal variances assumed } & \multirow{2}{*}{ Description } \\
\cline { 2 - 3 } & Sig. (2-tailed) & Asymp & \\
\hline $\begin{array}{l}\text { Concept } \\
\begin{array}{l}\text { Understanding } \\
\text { Ability }\end{array}\end{array}$ & 0.00 & Sig. $>0.05$ & $\begin{array}{l}\text { There is a } \\
\text { difference }\end{array}$ \\
\hline
\end{tabular}

Data presented in Table 1 shows that the Sig 2-tailed value of the independent $\mathrm{t}$-test results is $0.00(\mathrm{p}<0.05)$. Hence, it appears that there is a disparity between the conceptual understanding of learners who learned Islamic Religious Education learning using the Theoanthropocentric learning strategy with students who were not taught using the Theoanthropocentric learning strategy.

\section{Discussion}


Theoanthropocentric strategy in this study refers to the contextual strategy development approach. It emphasises that the source of knowledge comes from God and man himself. The Indonesian learning culture tends to involve spiritual and social contexts in achieving learning goals (Al Arifin, 2012; Fajarini, 2016); the spiritual context includes how the individual relates to God and how he performs worship based on his religious knowledge (Salleh, 2013). Meanwhile, the social context encompasses how an individual relates to other individuals and their environment and resolves problems in that relationship by utilising knowledge obtained from education and experience (Santoso, Nafis \& Oktama, 2019). This opinion is reinforced by the findings in Geertz (2013) findings, which explains that culture is part of the learning process and can influence how individuals carry out the learning process. Furthermore, learning with the Theoanthropocentric strategy, which is a part of contextual learning, can improve students' achievement (Satriani, Emilia \& Gunawan, 2015). Moreover, the findings of Rijal, Ilyasin, and Duraesa (2017) state that the Theoanthropocentric concept can be used to form a strengthening of an individual's faith in God and maintain social relations in his environment.

This study indicates that the Theoanthropocentric learning strategy can improve students' conceptual understanding skills in learning Islamic Religious Education. The higher conceptual understanding is obtained through implementing the learning steps using the Theoanthropocentric strategy. The first step involves students connecting and applying learning materials to the context of their social and spiritual life. This is in line with Suryawati and Osman (2017), which states that increased learning achievement can be obtained by connecting it and applying it to the context of students' daily lives. This process could make the material and information obtained more memorable to the students. Douglass and Shaikh (2004) stated that the habituation of terms derived from religious knowledge would shape students' understanding. Connecting material or information obtained from the learning process in social life helps students strengthen and expand their knowledge through social interaction (Fauzi \& Nikmatullah, 2016). Social interaction can also help improve students' mental health by increasing self-confidence in living community life and following a learning process (Dasopang, Erawadi, Lubis \& Hasibuan, 2020).

On the other hand, connecting material obtained in spiritual life can help students strengthen students' faith. They will realise the relationship between the 


\section{Fitrah \\ $\rightarrow$ Jurnal Kajian Ilmu-ilmu Keislaman}

Vol. 6 No. 2 December 2020

knowledge they get from learning with their spiritual experience (Salleh, 2013). The process will help students understand the concept of Islamic Religious Education. Students' understanding of concepts is also obtained from engaging students in connecting their social and spiritual experiences with learning. As supported by Cameron's (2011) findings, students will understand a given concept easily when the ideas are related to their lives or experiences. Forming an understanding of the concept of learning by utilizing student experiences is easier because students feel directly involved in learning (Asrizal, Amran, Ananda, Festiyed \& Khairani, 2018; Mackinnon, 2010). The use of the Theoanthropocentric approach in this contextual strategy will make it easier to relate to the students' spiritual lives with the learning process (Rohmanu, 2019).

Students will understand the concept and information they obtained during learning easier when the learning process is related to their environment (Ismail, Awang, Pyng \& Abdullah, 2020). Based on these findings, teachers could integrate students' experiences throughout the learning process to increase their conceptual understanding. Furthermore, involving students actively in the learning process could improve their conceptual understanding. Emaliana (2017) stated that student-centered learning is more effective than teacher-centered learning, as the students will feel more motivated in learning. Active student involvement in learning can lead to a sense of belonging and a sense of responsibility in the learning process (Bechter, Dimmock \& Jackson, 2019). Students' active role in learning can also help students explore the material presented and understand the concepts taught (Hsiao, Mikolaj \& Shih, 2017; Wong, 2020). In turn, higher motivation and a sense of responsibility in the learning process can help students achieve learning goals (Feszterova \& Jomova, 2015).

The learning process involving students' emotional and social relationships is another part of implementing the Theoanthropocentric strategy to improve students' understanding of concepts. Theoanthropocentric process encourages students to work cooperatively to gain knowledge through integrating students' emotional and social interactions in learning (Baloche \& Brody, 2017; Ehsan, Vida \& Mehdi, 2019; Tran, Nguyen, Van De, Soryaly \& Doan, 2019). Studies by Kalelkar (2017) and Slavin (2015) showed that group and collaborative learning could help teachers fulfill the learning objectives as it 
encourages information sharing between students. Students' conceptual understanding is developed through the group discussion process that allows the exchange of information, or knowledge between students. Frailich, Kesner \& Hofstein (2009) stated that the discussion process allows sharing of experience between students, impacting how students understand the concepts taught in the learning process. The knowledge transformation process also shows that social relations are a source of knowledge (Anthropocentric).

Furthermore, the discussion process could optimise concept understanding when teachers play a dominant and monotonous role in learning (Siregar, Rosli \& Maat, 2020). The principle Theocentric applies during the discussion process; namely, students must work together and carry out their responsibilities well to build students' characters. Gani's (2019) findings indicated that the formation of student morale is essential and an integral part of the learning objectives. In the meantime, Feszterova and Jomova (2015) stated that students' attitudes could help strengthen their spiritual learning. These findings are supported by Kamaluddin, Adawiyah, and Rusdin (2020), which stated that forming morals in education can strengthen the spiritual relationship between the students and God.

\section{CONCLUSION}

The Theoanthropocentric learning master plan has an effective and meaningful impact on the pupils' conceptual understanding abilities. The results show that students taught using the Theoanthropocentric learning strategy have a higher average score than those who were not exposed to it. The inferential statistical analysis using independent $\mathrm{t}$-test employed with Sig. $<0.05$ shows the differences in students' conceptual understanding abilities before and after the treatment using the Theoanthropocentric strategy and paired t-test. Furthermore, the paired t-test with Sig. $<0.05$ indicates that the treatment group of students scored better than in class control. This study's main contribution is to help teachers increase students' ability to understand by adopting the Theoanthropocentric contextual learning strategy in Islamic Religious Education learning. Moreover, this study has emphasised that while knowledge comes from God, man, specifically teachers, should help students relate the learning materials used in Islamic Religious Education to their own experience. Lastly, future studies can examine the effect of the Theoanthropocentric contextual learning approach in improving students' cognitive abilities. 


\section{Fitrah \\ $\triangle$ Jurnal Kajian Ilmu-ilmu Keislaman}

Vol. 6 No. 2 December 2020

\section{REFERENCES}

Al Arifin, A. H. (2012). Implementasi pendidikan multikultural dalam praksis pendidikan di Indonesia. Jurnal Pembangunan Pendidikan: Fondasi dan Aplikasi, 1(1), 72-82. doi:10.21831/jppfa.v1i1.1052

Al-Shehri, M. S. (2020). Effect of differentiated instruction on the achievement and development of critical thinking skills among sixth-grade science students. International Journal of Learning, Teaching and Educational Research, 19(10), 77-99. doi:10.26803/ijlter.19.10.5

Andamon, J., \& Tan, D. A. (2018). Conceptual understanding, attitude and performance in mathematics of grade 7 students. International Journal of Scientific E Technology Research, 7(8), 96-105.

Andayani, Y., Hadisaputra, S., \& Hasnawati, H. (2018). Analysis of the level of conceptual understanding. In Journal of Physics: Conference Series (Vol. 1095, p. 12045). doi :10.1088/1742-6596/1095/1/012045

Anderson, L. W., Krathwohl, D. R., Airasian, P. W., Cruikshank, K. A., Mayer, R. E., Pintrich, P. R., ... Wittrock, M. C. (2001). A taxonomy for learning, teaching, and assessing: A revision of bloom's taxonomy of educational objectives, abridged edition. White Plains, NY: Longman.

Asfar, A., \& Asfar, A. (2020). Case-based games learning strategies to improve conceptual understanding in mathematics. In Journal of Physics: Conference Series (Vol. 1663, p. 12060). IOP Publishing. doi:10.1088/1742$6596 / 1663 / 1 / 012060$

Asrizal, A., Amran, A., Ananda, A., Festiyed, F., \& Khairani, S. (2018). Effectiveness of adaptive contextual learning model of integrated science by integrating digital age literacy on grade VIII students. In Jurnal IOP Conferences Series: Materials Science and Engineering (Vol. 335, pp. 1-8). doi:10.1088/1757-899X/335/1/012067

Baloche, L., \& Brody, C. M. (2017). Cooperative learning: Exploring challenges, crafting innovations. Journal of Education for Teaching International Research and Pedagogy, 43(3), 274-283. doi:10.1080/02607476.2017.1319513

Bechter, B. E., Dimmock, J. A., \& Jackson, B. (2019). A cluster-randomized controlled trial to improve student experiences in physical education: Results of a student-centered learning intervention with high school 
teachers. Psychology of Sport and Exercise, 45, 101553. doi: 10.1016/j.psychsport.2019.101553

Biggerstaff, T. J., Mitbander, B. G., \& Webster, D. E. (1994). Program understanding and the concept assignment problem. Communications of The ACM, 37(5), 72-82.

Cameron, B. H. (2011). Experience-based learning. In Encyclopedia of Information Technology Curriculum Integration. doi:10.4018/978-1-59904-881-9.ch052

Clements, D. H., Sarama, J., \& DiBiase, A.-M. (2003). Engaging young children in mathematics: Standards for early childhood mathematics education. New Jersey: Routledge.

Corona, R., Alaniz, S., \& Akata, Z. (2019). Modeling conceptual understanding in image reference games. Advances in Neural Information Processing Systems, $32,1-11$.

Danver, S. L. (2016). Contextual teaching and learning. In The SAGE Encyclopedia of Online Education. doi:10.4135/9781483318332.n86

Dasopang, M. D., Erawadi, A. S., Lubis, A. A., \& Hasibuan, H. (2020). Analysis of students' mental health after terror cases in Indonesia. Systematic Reviews in Pharmacy, 11(2), 939-943.

Diem, H. T. T., \& Thathong, K. (2019). Enhancing the pre-service biology teachers to construct better lesson plans: A lesson study. International Journal of Learning, Teaching and Educational Research, 18(11), 218-231.

Ding, D., Guan, C., \& Yu, Y. (2017). Game-based learning in tertiary education: A new learning experience for the generation Z. International Journal of Information and Education Technology, 7(2), 148-152. doi:10.18178/ijiet.2017.7.2.857

Donisch, K., Bray, C., \& Gewirtz, A. (2016). Child welfare, juvenile justice, mental health, and education providers' conceptualizations of trauma-informed practice. Child Maltreatment, 21(2), 125-134.

Douglass, S. L., \& Shaikh, M. A. (2004). Defining Islamic education: Differentiation and applications. Current Issues in Comparative Education, 7(1), 5-18.

Edmondson, K. M. (2005). Assessing science understanding through concept 


\section{Fitrah \\ $\triangle$ Jurnal Kajian Ilmu-ilmu Keislaman}

Vol. 6 No. 2 December 2020

maps. Assessing Science Understanding, 15-40. doi:10.1016/b978-012498365$6 / 50004-4$

Ehsan, N., Vida, S., \& Mehdi, N. (2019). The impact of cooperative learning on developing speaking ability and motivation toward learning english. Journal of Language and Education, 5(3), 83-101. doi: 10.17323/jle.2019.9809

Emaliana, I. (2017). Teacher-centered or student-centered learning approach to promote learning? Jurnal Sosial Humaniora, 10(2), 59-70.

Fajarini, U. (2016). Peranan kearifan lokal dalam pendidikan karakter. Sosio Didaktika: Social Science Education Journal, 2(3), 75-90. doi:10.15408/sd.v1i2.1225

Fauzi, A., \& Nikmatullah, C. (2016). Pelaksanaan pendidikan madrasah diniyah di kota Serang. Jurnal Pendidikan dan Kebudayaan, 1(2), 157-178.

Feszterova, M., \& Jomova, K. (2015). Character of innovations in environmental education. Procedia - Social and Behavioral Sciences, 197, 1697 - 1702. doi:10.1016/j.sbspro.2015.07.222

Frailich, M., Kesner, M., \& Hofstein, A. (2009). Enhancing students' understanding of the concept ofchemical bondingby using activities provided on an interactive website. Journal of Research in Science Teaching, 46(3), 289-310. doi:10.1002/tea.20278

Gall, M. D., Borg, W. R., \& Gall, J. P. (1996). Educational research: An introduction. New York: Longman Publishing.

Gani, A. (2019). Urgency education morals of sufism in millennial era. Journal for the Education of Gifted Young Scientists, 7(3), 499-513.

Geertz, C. (2013). Religion as a cultural system. In Anthropological Approaches to the Study of Religion. doi:10.4324/9781315017570

Gwen, G. D. (2012). Philosophy of religion. In The Routledge Companion to Theism. doi:10.4324/9780203123294

Hsiao, E., Mikolaj, P., \& Shih, Y. (2017). A design case of scaffolding hybrid/online student-centered learning with multimedia. Journal of Educators Online, 14(1), 1-9. 
Huck, S. W., Cormier, W. H., \& Bounds, W. G. (1974). Reading statistics and research. New York: Harper \& Row

Ismail, R., Awang, M., Pyng, S. Y., \& Abdullah, M. R. B. (2020). Active learning in economic subject: a case study at secondary school. International Journal of Learning, Teaching and Educational Research, 19(10), 19-31. doi:10.26803/ijlter.19.10.2

Jack, B. M., \& Lin, H. (2017). Making learning interesting and its application to the science classroom. Studies in Science Education, 53(2), 137-164.

Johnson, B. E. (2006). Contextual teaching and learning. Bandung: Mizan.

Kalelkar, C. (2017). Classroom. Resonance, 22(7), 697-703. doi:10.1007/s12045-0170513-y

Kamaluddin, M., Adawiyah, A., \& Rusdin, R. (2020). Improving emotional and spiritual intelligence of students through aqidah morals. International Journal of Contemporary Islamic Education, 2(2), 91-107.

Khatimah, H., \& Sugiman, S. (2019). The effect of problem solving approach to mathematics problem solving ability in fifth grade. In Journal of Physics: Conference Series (Vol. 1157, pp. 1-7). doi:10.1088/1742-6596/1157/4/042104

Kim, J. (2018). Christian anthropology in an age of science: between anthropocentrism and non-anthropocentrism. The Expository Times, 129(12), 547-553.

Kurniasih, A. W., Hidayah, I., \& Asikin, M. (2020). Teacher support for eliciting students mathematical thinking: problem posing, asking questions, and song. International Journal of Learning, Teaching and Educational Research, 19(10), 265-285. doi: 10.26803/ijlter.19.10.15

Lubis, A. H., \& Wangid, M. N. (2019). Augmented reality-assisted picture storybook: media to enhance discipline character of primary school students. Mimbar Sekolah Dasar, 6(1), 11-20. doi:10.17509/mimbarsd.v6i1.13787

Mackinnon, T. (2010). Contextual learning. The International Journal of The Arts in Society: Annual Review, 5(4), 225-232. doi:10.18848/18331866/cgp/v05i04/35881

Marsh, M., Golledge, R., \& Battersby, S. E. (2007). Geospatial concept 


\section{Fitrah \\ I Jurnal Kajian Ilmu-ilmu Keislaman}

Vol. 6 No. 2 December 2020

understanding and recognition in g6-college students: A preliminary argument for minimal GIS. Annals of the Association of American Geographers, 97(4), 696-712.

Osborne, R. J., \& Gilbert, J. K. (1980). A method for investigating concept understanding in science. European Journal of Science Education, 2(3), 311321.

Palobo, M., Sianturi, M., Marlissa, I., Purwanty, R., Dadi, O., \& Saparuddin, A. (2018). Analysis of teachers' difficulties on developing curriculum 2013 lesson plans. In 1st International Conference on Social Sciences (ICSS 2018). Atlantis Press.

Perkinson, H. J. (2012). The culture of education. New Vico Studies. doi:10.5840/newvico19971510

Putra, F., Nur Kholifah, I. Y., Subali, B., \& Rusilowati, A. (2018). 5e-learning cycle strategy: Increasing conceptual understanding and learning motivation. Jurnal Ilmiah Pendidikan Fisika Al-Biruni, 7(2), 171-181. doi: 10.24042/jipfalbiruni.v7i2.2898

Quay, J. (2003). Experience and participation: Relating theories of learning. Journal of Experiential Education, 26(2), 105-112.

Rijal, S., Ilyasin, M., \& Duraesa, M. A. (2017). Religion, theology and terrorism in Indonesia: Reconstruction of theo-anthropocentric theology. International Journal of Philosophy and Theology 5(1), 36-46. doi: 10.15640/ijpt.v5n1a4

Riswanto, A., \& Aryani, S. (2017). Learning motivation and student achievement: Description analysis and relationships both. The International Journal of Counseling and Education, 2(1), 42-47.

Rohmanu, A. (2019). Paradigma hukum islam teoantoposentris: Telaah paradigmatis pemikiran Fazlur Rahman dan Abdullah Saeed. Kodifikasia, 13(1), 45-66. doi:10.21154/kodifikasia.v13i1.1679

Salleh, M. S. (2013). Strategizing Islamic education. International Journal of Education and Research, 1(6), 1-14.

Santoso, T., Nafis, H. L. H., \& Oktama, M. Y. (2019). Analyzing students' error in problem solving of two-variable linear equation system: A case study of grade eight students of Indonesian junior high school. International Journal 
of Learning, Teaching and Educational Research, 18(11), 283-296. 10.26803/ijlter.18.11.17

Santrock, J. W. (2011). Educational Psychology (5th ed.). New York: McGraw-hill Companies.

Satriani, I., Emilia, E., \& Gunawan, H. (2015). Contextual teaching and learning approach to teaching writing. Indonesian Journal of Applied Linguistics, 2(1), 10-22. doi:10.17509/ijal.v2i1.70

Schoenfeld, A. H. (2016). Research in mathematics education. Review of Research in Education, 40(1), 497-528. doi:10.3102/0091732X16658650

Schunk, D. H. (2012). Learning theories an educational perspective sixth edition. Boston: Pearson.

Siregar, N. C., Rosli, R., \& Maat, S. M. (2020). The effects of a discovery learning module on geometry for improving students' mathematical reasoning skills, communication and self-confidence. International Journal of Learning, Teaching and Educational Research, 19(3), 214-228. doi: 10.26803/ijlter.19.3.12

Slavin, R. E. (2014). Cooperative learning in elementary schools. Education 3-13, 43(1), 5-14. doi:10.1080/03004279.2015.963370

Suryawati, E., \& Osman, K. (2017). Contextual learning: innovative approach towards the development of students' scientific attitude and natural science performance. Eurasia Journal of Mathematics, Science and Technology Education, 14(1), 61-76.

Tran, V. D., Nguyen, T. M. L., Van De, N., Soryaly, C., \& Doan, M. N. (2019). Does cooperative learning may enhance the use of students' learning strategies?. International Journal of Higher Education, 8(4), 79-88.

Wardani, A. D., Gunawan, I., Kusumaningrum, D. E., Benty, D. D. N., Sumarsono, R. B., Nurabadi, A., \& Handayani, L. (2020). Student learning motivation: a conceptual paper. In 2nd Early Childhood and Primary Childhood Education (ECPE 2020) (pp. 275-278). Atlantis Press. doi:10.2991/assehr.k.201112.049

Wolfolk, A. (2016). Educational psychology (13th ed.). Boston: Pearson Education Inc.

Wong, K. M. (2020). A design framework for enhancing engagement in student- 


\section{Fitrah \\ $\triangle$ Jurnal Kajian Ilmu-ilmu Keislaman}

Vol. 6 No. 2 December 2020

centered learning: Own it, learn it, and share it" by Lee and Hannafin (2016): An International Perspective. Educational Technology Research and Development, 1-4. doi:10.1007/s11423-020-09842-w 